\title{
DISTRIBUTION AND SEASONAL ABUNDANCE OF FRESHWATER SNAILS IN SOME EGYPTIAN WATER COURSES
}

\author{
By \\ HANAA M.M. EL-KHAYAT, KADRIA M.A. MAHMOUD* AND SARA S.M. SAYED \\ Department of Environmental Research and Medical Malacology, Theodor Bilharz \\ Research Institute, P.O. Box 30, Imbaba, Giza, Egypt \\ ( ${ }^{\star}$ Correspondence:kadria11ma@hotmail.com)
}

\begin{abstract}
Mollusca play important role in the public and veterinary health and thus need to be study their distribution continuously. The present clarified the distribution and seasonal abundance of freshwater snails in the River Nile branches, main canals and some drains in eight Egyptian governorates during eight successive seasons. The highest percentage of snails' abundance in the River Nile was 33.6, 23, 22.1 and 20.8\% for Succinea cleopatra, Lanistes carinatus, Lymnaea natalensis and Cleopatra bulimoides snails, respectively. While Damietta and Ismailia canals were the mostly infested by snails in spring, Giza canals, Damietta branch and River Nile was in summer. During the whole study, the distribution of Lnatalensis was larger than Bulinus truncatus and Biomphalaria alexandrina. Results of correspondence analysis (CA) showed a good relationship between snail species and physical parameters explained 94.77, 94.12, 91.80 and $95.35 \%$ of variance in temperature, $\mathrm{pH}$, conductivity and dissolved oxygen, respectively. Values of physical parameters were approximately the same for all stations. In spite of the conductivity was high $1200 \mu \mathrm{mhos} / \mathrm{cm}$ in drains, other stations ranged from 200 to $800 \mu \mathrm{mhos} / \mathrm{cm}$.

Key wards: Egypt, Distribution, Seasonal variation, Lymnaea natalensis, Bulinus truncatus, Biomphalaria alexandrina.
\end{abstract}

\section{Introduction}

The pattern of schistosomiasis snail intermediate hosts distribution and prevalence of infection are among the measurable indicators that reflect the magnitude of transmission (Sayed et al, 2004). In Egypt, many investigators study the freshwater snail distribution and their population density especially the medically important ones through the Egyptian governorates. El-Hawey et al. (2000) and Mostafa et al. (2005) in Kafr ElSheikh and El-Gharbia Governorates reported that B. truncatus snails were not found among 60 examined sites and Schistosoma mansoni was completely replaced $S$. haematobium. A moderate to high decline in $B$. alexandrina and $B$. truncatus distribution respectively was observed in other Egyptian governorates; Giza, Dakahlia, Qalyobia and Ismailia (Abdel Kader, 2001; Ragab and Bakry, 2006). On the other hand, Ibrahim et al. (2005) studied distribution, ecology and population dynamics of $B$. alexandrina and $B$. truncatus in the River Nile at Greater Cairo from April 2001-March 2002 found that
$B$. alexandrina were less abundant than $B$. truncatus in the examined sector. Also, Biomphalaria spp. did not maintain stable populations striking fluctuations occur, at times seasonally as a result of human activity (Barbosa and Barbosa, 1994). Lymnaea spp.; the intermediate hosts of Fasciola gigantica and $F$. hepatica infected a wide variety of domestic animals, wildlife and people causing significant economic losses in African livestock (Mungube et al, 2006; Issia et al, 2009).

On the other hand, Hora and Pillay (1962) reported that the $\mathrm{pH}$ variation of water sources was mostly due to diurnal interplay of photosynthesis and community respiration of the biota and also is one of the most important single factors, which influences aquatic production.

Temperature is a vital parameter for growth of organisms. It plays an important role in physiological behavior of the aquatic system. It also influences the metabolic behavior of aquatic ecosystem (Welch, 1952). Dissolved oxygen could be linked with the 
self-purification capacity of moving water, aquatic plants' photosynthetic efficiency and airflow...etc (Singh and Tiwari, 1979). Conductivity increases with increasing amount and mobility of ions. These ions come from the breakdown of compounds. Therefore, it is an indirect measure of the presence of dissolved solids such as nutrients and can be used as an indicator of water pollution (Shivayogimath et al, 2012).

This work aimed to study distribution and seasonal abundance of freshwater snails Biomphalaria spp. Bulinus truncatus, (schistosomiasis) and (fascioliasis) Lymnaea spp. in different water courses in River Nile branches Damietta and Rosetta, also main canals and drains in some governorates.

\section{Materials and methods}

Study area: Samples were collected from 80 sites over 8 successive seasons (spring 2008 till winter 2010) from the River Nile, Damietta and Rosetta Branches, El-Tawfiki and El-Beheiry Rayahs, Ibrahimiyah canal, Bahr Youssef in Minya Governorate, El-Gizaweya, El- Khashab and Talkhn canals in Giza Governorate. Basoosiya, Sharkaweya, Abu El-Menagy, and El-Nahas canals in Qalyubia Governorate, El-Salam and AlSinanip canals in Damietta Governorate, El-
Khandak El-Sharky and Al Mahmudiya cannals in Beheira Governorate, Ismailia canal in Cairo, El-Sharkiya and Port Said canal in Ismailia Governorate were included. The drains were El-Moheet and El-Hood ElAreed in Minya and Giza Governorates, respectively and Abu Dongle and El-Serw drains in Damietta Governorate (Fig 1).

Samples of freshwater snails were collected from each site with a fixed number of five strikes using a standard dip net (Jobin, 1970; Yousif et al, 1992). At the same time, water physical parameters were recorded by portable equipment in the field. Dissolved oxygen was registered by dissolved oxygen meter electrode (HANNA HI 9146). Water temperatures and conductivity were measured by using temperature conductivity meter (HANNA instrument, HI 9635). Hydrogen ion concentration $(\mathrm{pH})$ was recorded by pH meter electrode (HI 9124 and HI 9125). In the lab the snails were sorted, identified and counted (Ibrahim et al, 1999).

Statistical analysis: Correlation patterns of the distribution of snail species and physical parameters were described by correspondence analysis (CA) using XLSTAT 2016, Statistical software for Microsoft Excel. Paris, France.

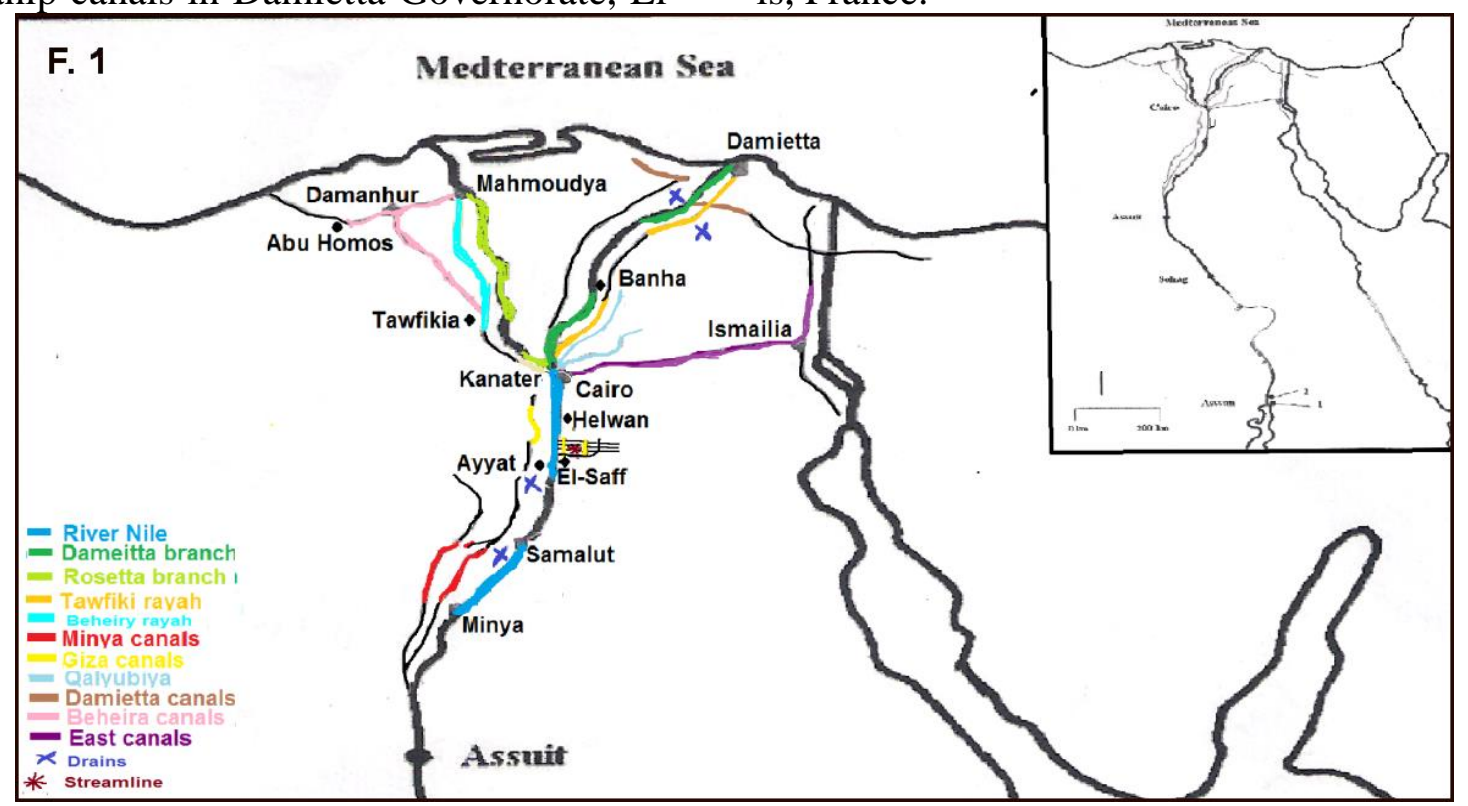

Fig 1: Map showing the studied Egyptian Governorates Cairo, Giza, Minya, Qalyubia, Damietta and Beheira, and Ismailia

\section{Results}

The results are shown in table (1) and figures (1, 2, 3, 4 \& 5). 
Table 1: Distribution percentage of different snail species among the examined watercourses.

\begin{tabular}{|c|c|c|c|c|c|c|c|c|c|c|c|}
\hline Snails species & $\frac{0}{z}$ & 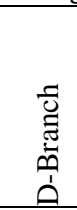 & 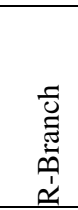 & 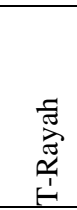 & 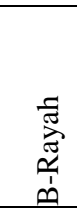 & 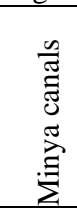 & 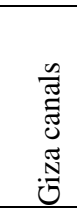 & 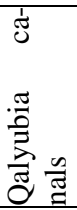 & 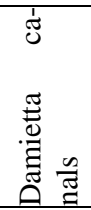 & 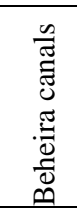 & 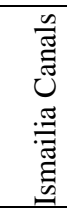 \\
\hline Biomphalaria alexandrina & 6.6 & 0.6 & 1.8 & 0.0 & 0.0 & 0.0 & 69.5 & 3.6 & 0.0 & 0.0 & 15.0 \\
\hline Bulinus truncatus & 7.9 & 16.0 & 1.4 & 4.5 & 7.4 & 4.1 & 1.8 & 1.6 & 31.4 & 3.8 & 19.4 \\
\hline Lymnaea natalensis & 22.1 & 7.8 & 1.3 & 6.3 & 2.3 & 0.4 & 5.3 & 1.0 & 7.8 & 6.1 & 37.0 \\
\hline Lanistes carinatus & 23.0 & 11.3 & 0.1 & 4.9 & 1.0 & 5.9 & 1.3 & 7.7 & 13.0 & 6.5 & 24.7 \\
\hline Cleopatra bulimoides & 20.8 & 11.4 & 0.2 & 0.6 & 1.9 & 11.6 & 2.6 & 1.5 & 13.7 & 4.4 & 30.0 \\
\hline Physa acuta & 11.5 & 1.9 & 3.3 & 1.1 & 1.4 & 0.7 & 56.0 & 4.7 & 8.8 & 1.3 & 7.5 \\
\hline Bellamya unicolor & 16.7 & 10.9 & 11.3 & 15.8 & 0.9 & 7.2 & 0.9 & 2.7 & 6.3 & 7.2 & 19.9 \\
\hline Helisoma duryi & 0.7 & 22.4 & 2.2 & 1.0 & 0.2 & 0.0 & 0.0 & 0.0 & 0.7 & 2.7 & 69.8 \\
\hline Melanoides tuberculata & 13.9 & 9.3 & 3.7 & 0.0 & 0.9 & 11.1 & 8.3 & 1.9 & 20.4 & 10.2 & 20.4 \\
\hline Theodoxus niloticus & 16.4 & 4.4 & 0.5 & 0.5 & 3.0 & 10.6 & 0.0 & 7.3 & 22.2 & 6.3 & 28.4 \\
\hline Succinea cleopatra & 33.6 & 9.0 & 0.9 & 5.7 & 9.0 & 1.4 & 9.0 & 8.1 & 7.1 & 3.3 & 12.3 \\
\hline Planorbis planorbis & 9.1 & 0.0 & 0.0 & 0.0 & 0.0 & 0.0 & 0.0 & 0.0 & 54.5 & 9.1 & 27.3 \\
\hline Valavat nilotica & 0.0 & 81.3 & 0.0 & 0.0 & 12.5 & 0.0 & 0.0 & 6.3 & 0.0 & 0.0 & 0.0 \\
\hline Species richness & 12 & 12 & 11 & 9 & 11 & 9 & 9 & 11 & 11 & 11 & 12 \\
\hline
\end{tabular}

\section{Discussion}

In the present work, $B$. alexandrina was the most abundant in Giza canals (69.5\%), then Ismailia canals (15\%) and the River Nile $(6.6 \%)$. While B. truncatus found in all water courses with the maximum abundance in Damietta (31.4\%) followed by Ismailia canals $(19.4 \%)$ and $(7.9 \%)$ in the River Nile. This results agrees with the findings of Ibrahim et al. (2005) who studied the distribution of $B$. alexandrina and B. truncatus in the River Nile at Greater Cairo and revealed that $B$. alexandrina were less abundant than B. truncatus. Also, the present data revealed that $L$. natalensis $(22.1 \%)$ was more abundant than $B$. alexandrina $(6.6 \%)$ and $B$. truncates $(7.9 \%)$ in the River Nile.

Succinea cleopatra and Lanistes carinatus recorded high percent in the River Nile (33.6 and $23 \%$ ) respectively, followed by $L$. $n a-$ talensis (22.1\%) and C. bulimoides (20.8\%). Also, the present study exhibited that Physa acuta showed the maximum abundance in Giza canals $(56.0 \%)$ then the River Nile $(11.5 \%)$. Bellamya unicolor is distributed in all examined watercourses except drains and dominates in Ismailia canals $(19.9 \%)$ and the River Nile (16.7\%). Helisoma duryi was found only in eight watercourses and dominates in Ismailia canals (69.8\%). M. tuberculata was distributed in the watercourses examined except Tawfiki Rayah and the drains
T. niloticus maximum abundance was recorded in Ismailia canals $(28.4 \%)$ and Damietta canals $(22.2 \%)$, the River Nile (16.4\%) and then Minya canals (10.6\%). Succinea cleopatra was most abundant in the River Nile (33.6\%). Planorbis planorbis was found only in four watercourses and showed the maximum abundant in Damietta canals then Ismailia canals followed by the River Nile and Beheira canals. Valvata niloticus was found only in three watercourses and the most abundant was recorded in Damietta branch then Beheiry Rayah followed by Qalyubia canals.

The present study also showed that the maximum species richness was recorded in the River Nile, Damietta branch and Ismailia canals (12 species), then Rosetta branch, Beheiry Rayah, Qalyubia, Damietta and Beheira canals (11), followed by Tawfiki Rayah, Minya canals and Giza canals (9) and at last the drainages (8). The detected snail species in the present study were recognized by El-Kady et al. (2000) in El-Abtal village situated on the east of Ismailia governorate. Also, Fisher and Williams (2006) recorded nineteen species of molluscs at the River Nile from Aswan to Cairo; including all species observed in the present study. This agreed with Abd El-Wakeil et al. (2013) who study the River Nile and branches in 
Assiut governorate, Egypt who found twenty species of Gastropoda; most of them were detected in the present study except (Gabbiella senaariensis ; Lanistes varicus; Pila ovata (Olivier); Pila wernei; Pseudosuccinea columella; Bithynia connollyi (Gardner); Hydrobia aponensis (Martens) and Gyraulus ehrenbergi). Ramadan et al. (2000) recognized fourteen gastropods species between Esna and El-Kanater El Kharia. Hussein et al. (2011) recorded thirteen species in Qena Governorate.

Seasonal variations in terms of their influence on the change species abundance rather than complete species replacement in the aquatic systems were reported (Brooks, 2000; Mesa, 2012). Impact of seasonal variation in the distribution of snail species among different water courses of the present study showed that Damietta and Ismailia canals was the mostly infested by snails in spring then Giza canals and Damietta branch followed by the River Nile in summer. This agreed with Abd El-Wakeil et al. (2013) who stated that the maximum species richness and diversity of molluscan community in spring and summer months.

The present results indicated that B. alexandrina exhibited two peaks in spring and autumn 2009, while approximately disappeared in summer and winter seasons. $B$. truncatus and $T$. niloticus was found all around year - 2009 exhibiting two peaks during spring and autumn. L. natalensis and $P$. acuta were found around the year exhibiting peaks during spring and winter 2009. This agreed with Marie et al. (2015) who exhibited that B. alexandrina; P. acuta; $L$. natalensis and $B$. truncatus showed the highest peak in spring season. On the other hand, $L$. carinatus and $H$. duryi were found with sharp peak during summer 2009. And $C$. bulimoides showed a high peak during spring 2009. Also, B. unicolor was found with two peaks during summer and autumn 2009. Meanwhile, Marie et al. (2015) reported that $B$. unicolor showed two peaks in spring and summer seasons. In the present work, M. tuberculata was found with high peak in autumn 2008 and summer 2009 and disappeared during spring $2008 \& 2009 . S$. cleopatra was found with high peak during winter $2008 \& 2009$. This result is in parallel with previously recorded by Marie et al. (2015) who stated that the highest peak of $S$. cleopatra in winter. Planorbis planorbis was found with high peak during autumn 2008.

From the total samples of collected snails during the whole study period, P. acuta has the highest percentage of representation (24.5\%) among different snail species followed by C. bulimoides (16.4\%), L. carinatus (15.2\%), L. natalensis (9.2\%), B. truncatus (7.8\%), T. niloticus (7.5\%), H. duri (7.1\%), B. unicolor (3.9\%), S. cleopatra (3.7\%), B. alexandrina (3\%), M. tuberculata (1.2\%), V. nilotica $(0.28 \%)$ and at last $P$. planorbis $(0.19 \%)$ (Fig.4) this is means that the distribution of $B$. alexandrina $<B$. truncatus $<$ L. natalensis.

Kloos and David (2002) demonstrated changes in the distribution of $B$. truncatus populations and repopulation of the snails in canals of Damietta and Ismailia Governorates. Biomphalaria spp. snails which were previously restricted to the Delta are now being found in Upper Egypt.

In the present study, the water temperature was ranged from $24-29^{\circ} \mathrm{C}$ during spring, $25-$ $33^{\circ} \mathrm{C}$ during summer, $21-24^{\circ} \mathrm{C}$ during autumn and $18-22{ }^{\circ} \mathrm{C}$ during winter. $\mathrm{pH}$ was ranged from 6.2-7.3 and conductivity was ranged from 284 to $857 \mu \mathrm{moh} / \mathrm{Cm}$, while dissolved oxygen was ranged from 2 to 6 $\mathrm{mg} / \mathrm{L}$. Generally, the Correspondence Analysis (CA) showed a good relationship between snail species and physical parameters explained $94.77 \%, 94.12 \%, 91.80 \%$ and $95.35 \%$ of the variance in temperature, $\mathrm{pH}$, and conductivity and dissolved oxygen variables data respectively.

Temperature played an important role in the physico-chemical and physiological behavior of the aquatic system (Alaka, 2014).

The present study showed that B. alexandrina, $P$. acuta and $V$. niloticus snail species 
were associated with $25-30^{\circ} \mathrm{C}$ temperature. On the other hand, B. truncatus, L. natalensis, $P$. planorbis, T. niloticus, $M$. tuberculata, S. cleopatra, L. carinatus and $H$. duri snail species were found in water temperature ranged $18-24^{\circ} \mathrm{C}$. Moreover, the most tolerant snail species for high temperature $>$ $30^{\circ} \mathrm{C}$ was Corbicula consobrina (bivalvaia). Also, temperature plays a key role in determination of other parameters such as conductivity; level of gases and various alkalinity forms (Esmaeili and Johal, 2005; Negi et $a l, 2007)$. The $\mathrm{pH}$ was changed with time due to temperature changes, and therefore is considered to be an important ecological factor. Aquatic organisms are affected by $\mathrm{pH}$ because most of their metabolic activities were dependent on $\mathrm{pH}$ (Wang et al, 2009).

In the present study, the most of the snail species were found in $\mathrm{pH}$ range (4-6) and avoid low acidity less than 4 and/or high alkalinity more than eight. Except $S$. cleopatra snails that were found in $\mathrm{pH}$ range (6.1-8). In the same pattern, results of conductivity showed that the most snail species distributed in conductivity range $(270-400 \mu \mathrm{mhos}$ $/ \mathrm{cm})$, while $P$. planorbis snails associated with conductivity range $(401-800 \mu \mathrm{mhos} /$ $\mathrm{cm})$. On the other hand, T. niloticus, S. cleopatra, L. carinatus, C. consobrina and $V$. niloticus snails found in $<270 \mu \mathrm{mhos} / \mathrm{cm}$ conductivity level. Moreover, there were no snail species found in $>800 \mu \mathrm{mhos} / \mathrm{cm}$ conductivity level. High concentration of acid, base or salt in water increased; Electrical Conductivity (EC) of that water (Arya and Mishra, 2015).

In summer due to greater evaporation, concentration of salts gets increased so as to show a higher EC; during winter due to precipitation results dilution makes value reduced (Trivedy and Goel, 1984). Low content of the dissolved oxygen could be linked with moving water, the aquatic plants' photosynthetic efficiency (Singh and Triweri 1979).

The present study showed that $P$. acuta tolerated low dissolved oxygen below 0.5
mg/L. Meanwhile, V. niloticus, B. unicolor and $H$. duri associated with $(0.5-2 \mathrm{mg} / \mathrm{L})$ dissolved oxygen range. The other snail species favorite to associate with dissolved oxygen more than $5 \mathrm{mg} / \mathrm{l}$. Reduction of organic matters needed a large amount of DO, usually low DO in summer (Mamta and Ranga, 2012). Investigating ecology of freshwater snails have shown that the distribution of these animals depend on the physical geography of a given region. So, physical, chemical and biological factors can have a significant effect on population dynamics of fresh water snails (Barbosa and Barbosa, 1994).

\section{Conclusion}

Generally speaking, the freshwater molluscs are important for medical and veterinary public health authorities. So, studying the seasonal abundance of freshwater snails of medical importance will be helpful in planning for strategies of controlling veterinary and medically important parasitic diseases.

\section{Acknowledgement}

This work was a part from project $80 \mathrm{M}$. entitled; Assessment of certain freshwater bodies' environment in some Egyptian Governorates.

\section{References}

Abdel Kader, A, 2001: The effect of ecological parameters on the distribution of snail vectors of schistosomiasis. J. Egypt. Soc. Parasitol. 31:14552.

Abd El-Wakeil, KF, Obuid-Allah, AH, Mohamed, AH, Abd El-Aziz, FA, 2013: Community structure of molluscs in River Nile and its branches in Assiut governorate, Egypt. Egypt. J. Aqua. Res. 39:193-8.

Alaka, AP, 2014: Limnological and correlation studies of canal water body of Sangli, Maharashtra. Int. Res. J. Environ. Sci. 3, 9:43-9.

Arya, M, Mishra, AK, 2015: Studies on physico-chemical characteristics of the Madhav Lake, Shivpuri, M.P., India IOSR. J. Environ. Sci. 9: 10-4.

Brooks, RT, 2000: Annual and seasonal variation and the effects of hydroperiod on benthic macroinvertebrates of seasonal forest "vernal" ponds in central Massachussets, USA. Wetlands 20, 4:707-15. 
Barbosa, SF, Barbosa, CS, 1994: The bioecology of snail vectors for schitosomiasis in Brazil. Cad. Saúde Públ., Rio de Janeiro, 10, 2:200-9.

El-Hawey, AM, Amer, MM, Abdel Rahman, AH, El-liary, SA, Agina, AM, et al, 2000: The epidemiology of schistosomiasis in Egypt: Gharbia Governorate. Am. J. Trop. Med. Hyg. 62:4248.

El-Kady, GA, Shoukry, A, Reda, LA, El-Badri, YS, 2000: Surveyand population dynamics of freshwater snails in newly settled areas of the Sinai Peninsula. Egypt. J. Biol. 2:42-8.

Esmaeili H, Johal MS, 2005: The national seminar, new trends in fishery development in India Streams. Braz. Arch. Biol. Technol. 55:403-10.

Fishar, MR, Williams, WP, 2006: A feasibility study to monitor the macro-invertebrate diversity of the River Nile using three sampling methods. Hydro. 55, 6:137-47.

Hora, SL, Pillay TVR, 1962: Handbook of fish culture in the Indo-Pacific region. FAO Fish. Biol. Tech. Pap. 14:204-9.

Hussein, MA, Obuid-Allah, AH, Mahmoud, A A, Fangary, HM, 2011: Population dynamics of freshwater snails (Mollusca: Gastropoda) at Qena Governorate, Upper Egypt. Egypt. Acad. J. Biol. Sci. 3, 1:11-22.

Ibrahim, A M, Bishai, H M, Kaslil, MT, 1999: Fresh Water Molluscs of Egypt Publications of National Biodivesrsity Unit, No. 10.

Ibrahim, AM, Yousif, F, El-Hommossany, K 2005: Ecological studies on schistosome vector snails in the River Nile at greater Cairo. J. Environ. Sci. 11:19-37.

Jobin, WR, 1970: Population dynamics of aquatic snails in three farm ponds in Puerto Rico. Amer. J. Trop. Med. Hyg. 19:1038-48.

Issia, L, Pietrokovsky, S, Sousa-Figueiredo, J, Stothard, JR, Wisnivesky-Colli, C, 2009: Fasciola hepatica infections in livestock flock, guanacos and coypus in two wildlife reserves in Argentina. Veter. Parasitol. 165:341-4.

Kloos, H, David, R, 2002: The paleoepidemiology of schistosomiasis in Ancient Egypt. Human Ecol. Rev. 9:14-25.

Mamta, T, Ranga, MM, 2012: Assessment of diurnal variation of physico-chemical status of Khanpura. Res. J. Chem. Sci. 7, 2:69-71.

Mesa, LM, 2012: Intrannual \& seasonal variability of macroinvertebrates in monsoonal climate streams. Brazil. Arch. Biol. Tech. 55:403-10.
Mostafa, BB, Abdel Kader, A, Tantawy, AA, 2005: Distribution of snail vectors of schistosomiasis and facioliasis and infection risks at some rice farming sites in Kafr El-Sheikh and ElGharbia Governorates, Egypt: the present status. J. Egypt. Ger. Soc. Zool., 46, D:53-65.

Marie, MA, El-Deeb, F, Hasheesh, W, Atef, R, Sayed, S, 2015: Impact of seasonal water quality and trophic levels on the distribution of various freshwater snails in four Egyptian Governorates. Appl. Ecol. Environ. Sci. 4:117-26.

Mungube, EO, Bauni, SM, Tenhagen, BA, Wamae, LW, Nginyi, JM, et al, 2006: The prevalence and economic significance of Fasciola gigantica and Stilesia hepatica in slaughtered animals in the semi-arid coastal Kenya. Trop. Anim. Hlth. Proc. 38:475-83.

Negi, RK, Johal, MS, Negi,T, 2001: Study of the Physico-chemical parameters of water of Pong dam reservoir, Himachal Pradesh: A. Ramsar site, Him. J. Environ. 20, 2:247-51.

Ragab, FMA, Bakry, FA, 2006: Survey of fresh water snails for medically important parasites in three villages of El-Saff District, Giza Governorate. Egypt. J. Biol. Environ. Sci. 1:135-45.

Ramadan, SE, Khirallah, AM, Abdel-Salam, KM, 2000: Benthic communities in the Nile River, Egypt II- Mollusca. Bull. Inst. Oceanogr. Fish. 26:149-66.

Sayed, HA, El-Ayyat, A, Abdel Kader, A, Sabry, H, Amer, N, 2004: Epidemiology of Schistosoma mansoni infection and its relationship to snail distribution in a village at the Nile Bank south to Cairo. J. Egypt. Pub. Hlth. Assoc. 79: 95-113.

Singh, SK, Tiwari RK, 1979: The impact of sewage water on the quality of Ganga River, Mendel. 6, 10:99-101.

Shivayogimath, CB, Kalburgi, PB, Deshannavar, UB, Virupakshaiah, DBM, 2012: Water quality evaluation of river Ghataprabha, India, Int. Res. J. Environ. Sci. 1, 1:12-8.

Trivedy, RK, Goel, PK, 1984: Hand book of Chemical and Biological Methods for Water Pollution Studies: Environmental Publications, Karad, Maharashtra (India).

Welch, PS, 1952: Limnology, McGraw Hill Book CO., New York, USA. $2^{\text {nd }}$ edition.

Yousif, F, Khalil, M, El-Emam, M, 1992:

Evaluation of three common tools in estimating Biomphalaria alexandrina population in irrigation ditches. Egypt. J. Bilh. 14:151-8. 


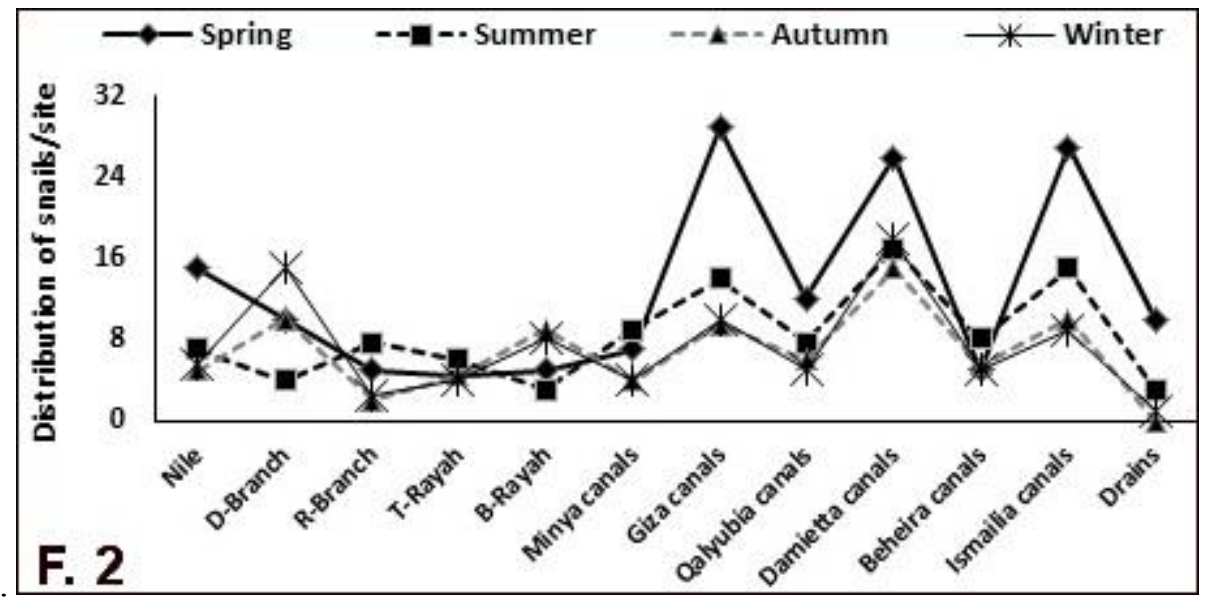

Fig 2: distribution of snail species among different water courses during seasons.

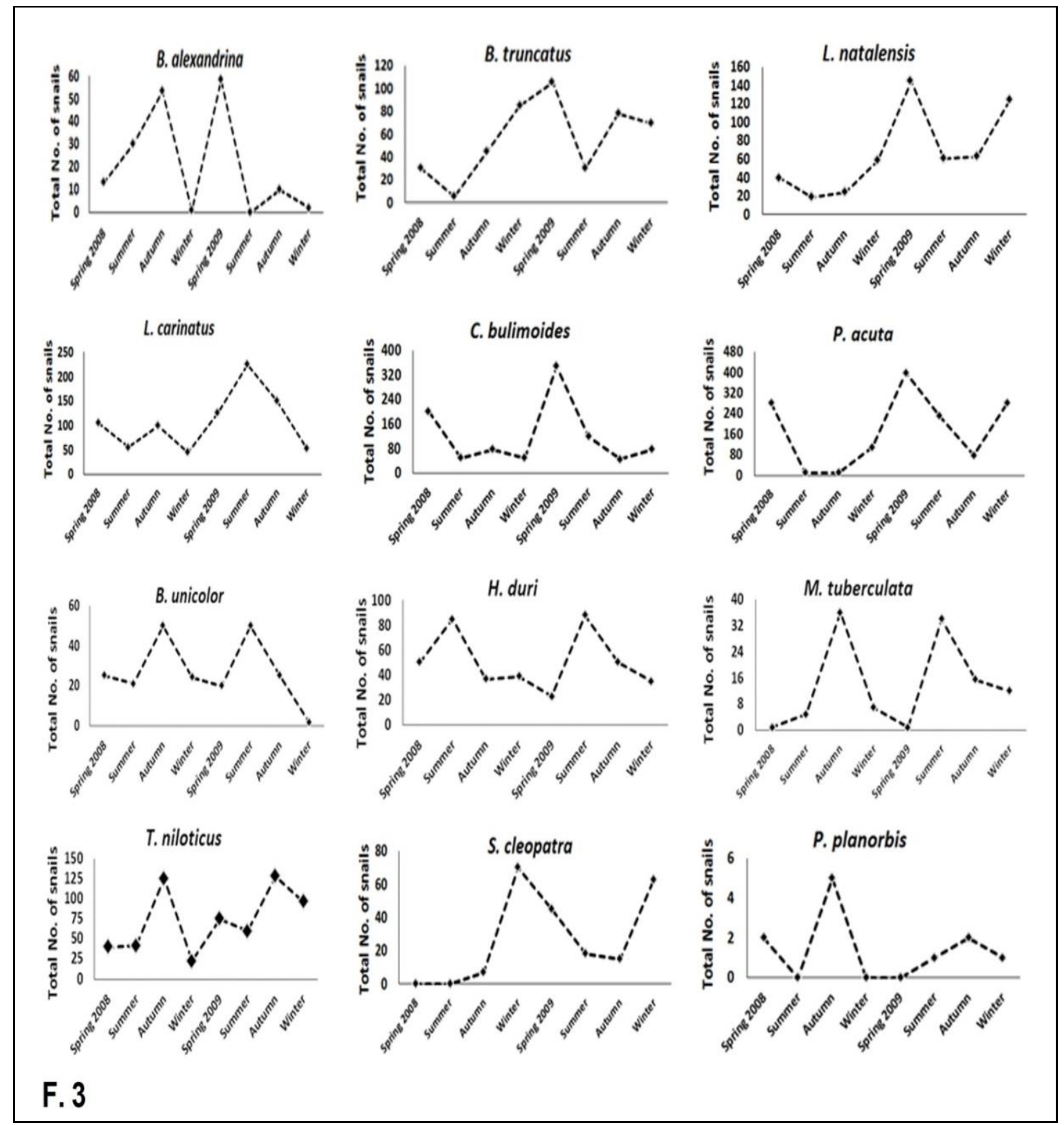

Fig 3: Seasonal fluctuations in abundance of snail species during years 2008/2009 and 2009/2010. 


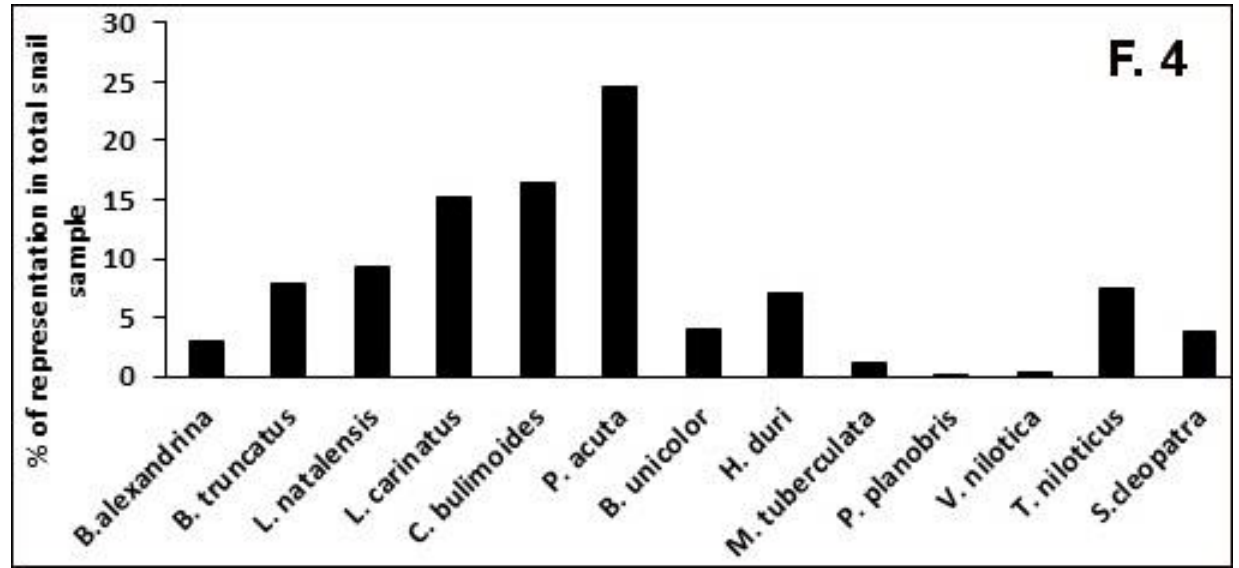

Fig 4: Percentage of representation of different snail species among total sample of snails collected from different watercourses.

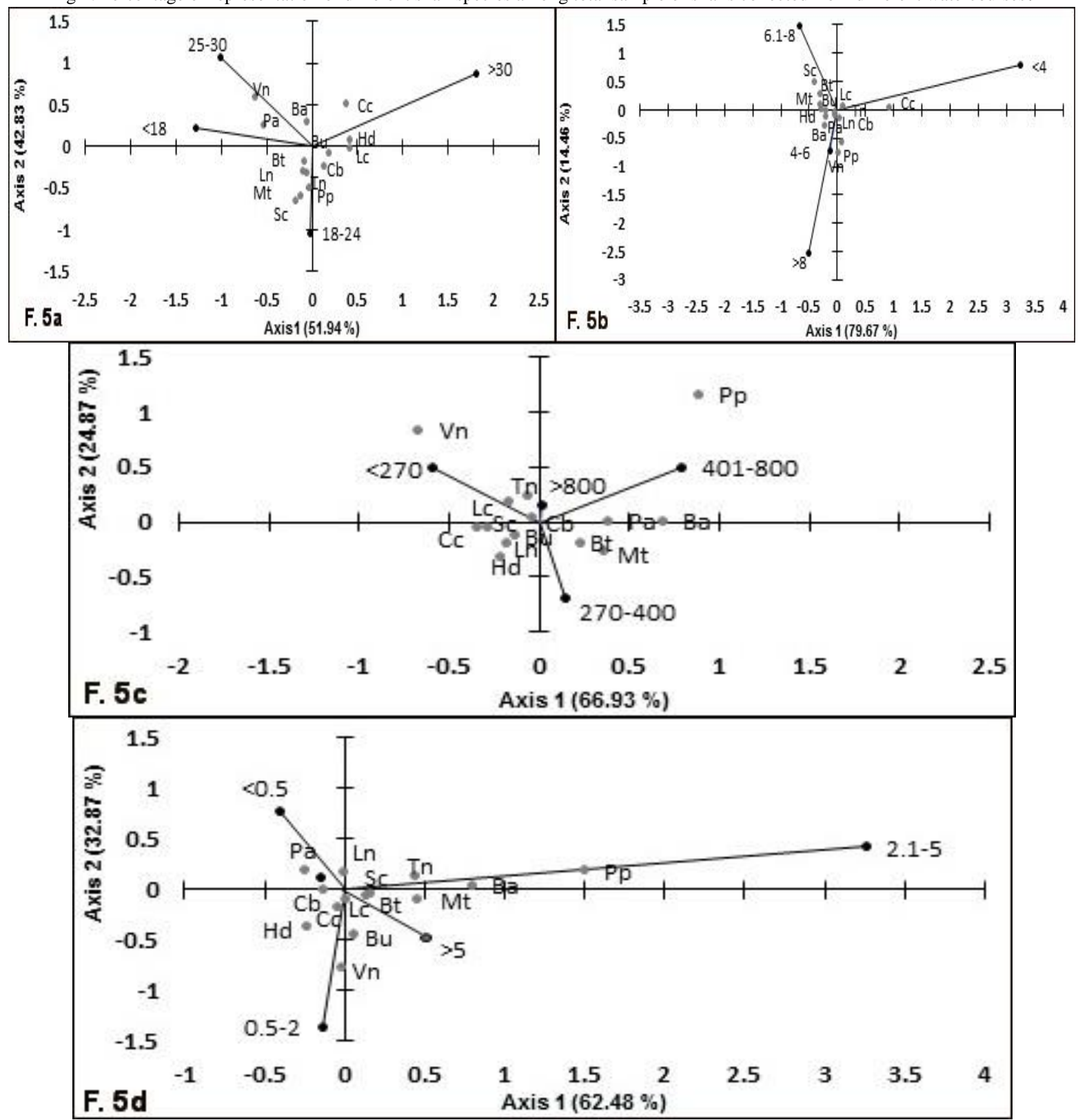

Fig. 5: correlation between snail species and temperature (a), $\mathrm{pH}$ (b), conductivity (c) and dissolved oxygen (d) ranges biplot by correspondence analysis. 